\title{
"ANALISIS PENGARUH TAX AMNESTY BAGI BEI KANTOR PERWAKILAN YOGYAKARTA" \\ ( Studi Pada Bursa Efek Indonesia) Di Yogyakarta
}

\author{
Nabilla Chintia Agni Cikhita \\ Program Studi Akuntansi Fakultas Ekonomi \\ Universitas Mercu Buana Yogyakarta \\ nabila@gmail.com
}

\begin{abstract}
Abstrak
Skripsi ini membahas tentang "Analisis Pengaruh Tax amnesty Bagi BEI Kantor Perwakilan Yogyakarta (Studi Bursa Efek Indonesia) di Yogyakarta”. Tujuan penulisan skripsi ini adalah Untuk mengetahui seberapa besar pengaruh dari program Tax amnesty dan untuk mengetahui penerapan Tax amnesty dalam meningkatkan saham pasar modal pada Bursa Efek Indonesia Kantor Perwakilan Yogyakarta. Penulisan skripsi ini membahas pada adanya pengaruh, manfaat, kelebihan dan kekurangan Tax amnesty, serta tata cara penyampaian tax amnesty, fasilitas dan juga periode pelaksaan tax amnesty. Data yang digunakan adalah data sekunder berupa laporan perputaran harga saham tiap-tiap industri dan diambil pada saat berlangsungnya tax amnesty.
\end{abstract}

Kata Kunci: Tax amnesty, BEI, Sekunder

\section{"ANALYSIS OF EFFECT OF TAX AMNESTY FOR BEI REGENCY OF YOGYAKARTA REPRESENTATIVES " (Study On Indonesia Stock Exchange) In Yogyakarta}

\author{
Nabilla Chintia Agni Cikhita \\ Program Studi Akuntansi Fakultas Ekonomi \\ Universitas Mercu Buana Yogyakarta \\ nabila@gmail.com
}

\begin{abstract}
This thesis discusses about 'The Influence of tax amnesty for Indonesia Stock Exchange of Yogyakarta Representative Office (Study of Indonesia Stock Exchange) in Yogyakarta'. The purpose for writing this thesis is to find out about how big is the influence and the implementation of tax amnesty to increase the stock market shares in Indonesia Stock Exchange of Yogyakarta Representative Office. This thesis mainly discuss about the influence, benefits, advantages and disadvantages of tax amnesty, as well as tax amnesty submission, facilites and also the period of tax amnesty implementation. The data used was secondary data in the form of stocks turnover table from each industry, taken within the period of tax amnesty implementation.
\end{abstract}

Keyword: Tax amnesty, BEI, secondary 


\section{PENDAHULUAN}

Pembangunan nasional yang berlangsung secara terus-menerus dan berkesinambungan selama ini, bertujuan meningkatkan kesejahteraan rakyat baik materiil dan spiritual. Untuk merealisasikan tujuan tersebut diperlukan anggaran pembangunan yang cukup besar. Salah satu usaha untuk mewujudkan peningkatan penerimaan untuk pembangunan tersebut adalah dengan menggali sumber dana yang berasal dari dalam negeri, yaitu pajak. Secara ekonomi, pemungutan pajak merupakan penerimaan negara yang digunakan untuk meningkatkan taraf kehidupan masyarakat. (Mulyo Agung, 2007).

Untuk menggali penerimaan negara dari sektor perpajakan dibutuhkan upayaupaya nyata, serta diimplementasikan dalam bentuk kebijakan pemerintah. Upaya-upaya tersebut dapat berupa intensifikasi maupun ekstensifikasi perpajakan. Intensifikasi pajak dapat berupa peningkatan jumlah Wajib Pajak (WP) maupun peningkatan penerimaan pajak itu sendiri. Upaya ekstensifikasi dapat berupa perluasan objek pajak yang selama ini belum tergarap. Untuk mengejar penerimaan pajak, perlu didukung situasi sosial ekonomi politik yang stabil, sehingga masyarakat juga bisa dengan sukarela membayar pajaknya. Pemerintah tentu diharapkan dapat mempertimbangkan kembali kebijakan perpajakan yang bisa menarik minat masyarakat menjadi wajib pajak seperti sunset policy. Demikian juga, salah satu kebijakan yang perlu dipertimbangkan adalah diberikannya Tax amnesty atau pengampunan pajak. Kebijakan ini diharapkan dapat meningkatkan subyek pajak maupun obyek pajak. Subyek pajak dapat berupa kembalinya dana-dana yang berada di luar negeri, sedangkan dari sisi obyek pajak berupa penambahan jumlah wajib pajak.

Sesuai dengan latar belakang penelitian yang dikemukakan di atas, maka penulis mencoba merumuskan masalah yang akan dibahas dalam penelitian ini adalah sebagai berikut :

1. Seberapa besar pengaruh dari program Tax amnesty?

2. Seberapa besar pengaruh program Tax amnesty dalam meningkatkan saham pasar modal di Bursa Efek Indonesia Kantor Perwakilan Yogyakarta?

\section{Batasan Masalah}

Agar penulisan skripsi ini tidak menyimpang dan mengambang dari tujuan yang semula direncanakan sehingga mempermudah mendapatkan data dan informasi yang diperlukan, maka penulis menetapkan batasan - batasan sebagai berikut: 
1. Periode pengambilan data di Bursa Efek Indonesia yakni pada bulan Juli tahun 2016 hingga Maret tahun 2017 sebagai pembanding adanya perubahan bursa saham sebelum dan sesudah adanya program Tax amnesty.

2. Data yang diambil merupakan data dari pergerakaan saham sebelum dan saat periode berlangsungnya program Tax amnesty di Bursa Efek Indonesia Kantor Perwakilan Yogyakarta.

3. Data yang diambil hanya sebatas data per jenis masing-masing industry yang ada di Bursa Saham.

\section{Tujuan Penelitian}

Dalam setiap kegiatan yang dilakukan pasti memiliki suatu tujuan. Demikian juga penelitian ini memiliki beberapa tujuan dalam hubungannya dengan obyek penelitian, yaitu:

1. Untuk mengetahui seberapa besar pengaruh dari program Tax amnesty.

2. Untuk mengetahui penerapan Tax amnesty dalam meningkatkan saham pasar modal pada Bursa Efek Indonesia Kantor Perwakilan Yogyakarta.

\section{Metodologi Penelitian dan kerangka penulisan skripsi}

\section{METODE}

Bahan-bahan dan informasi berasal dari data sekunder yang didapat dari penggalian informasi dari berbagai sumber, bahan seminar, media masa, media elektronik, dan lain-lain serta didukung pula dengan tinjauan pustaka.

\section{LANDASAN MASALAH}

\section{Tinjauan Pustaka}

Pembangunan di Indonesia sangatlah penting untuk mensejahterakan masyarakat. Dalam pembangunan, tidak akan tercapai apabila tidak ada kerja sama antara pemerintah dan masyarakat, hal ini ditujukan agar pembangunan tersebut berjalan sesuai dengan keinginan masyarakat dan bangsa Indonesia. Disamping itu ada hal yang sangat berpengaruh terhadap pembangunan yaitu dana atau biaya untuk pembangunan itu sendiri. Salah satu sumber dana yang paling besar adalah dari pajak.

\section{Pengertian Pajak}

Menurut Rimsky K. Judisseno (2005:7), Pajak adalah suatu kewajiban kenegaraan dan pengabdian serta peran aktif warga negara dan anggota masyarakat lainnya untuk membiayai berbagai keperluan negara berupa Pembangunan Nasional yang pelaksanaannya diatur dalam UndangUndang dan peraturanperaturan untuk tujuan kesejahteraan bangsa dan negara. Menurut Undang-Undang No.16 Tahun 2009, tentang perubahan keempat atas 
Undang-Undang dan tata cara perpajakan pada pasal 1 ayat 1 berbunyi, pajak adalah kontribusi wajib kepada negara yang terutang oleh orang pribadi atau badan yang bersifat memaksa berdasarkan Undang-Undang, dengan tidak mendapatkan imbalan secara langsung dan digunakan untuk keperluan negara bagi sebesar-besarnya kemakmuran rakyat.

\section{Pengertian Tax amnesty}

Tax amnesty adalah program pengampunan yang diberikan oleh Pemerintah kepada Wajib Pajak meliputi penghapusan pajak yang seharusnya terutang, penghapusan sanksi administrasi perpajakan, serta penghapusan sanksi pidana di bidang perpajakan atas harta yang diperoleh pada tahun 2015 dan sebelumnya yang belum dilaporkan dalam SPT, dengan cara melunasi seluruh tunggakan pajak yang dimiliki dan membayar uang tebusan.

\section{- Tujuan Tax amnesty}

1. Repatriasi atau menarik dana warga negara Indonesia yang ada di luar negeri.

2. Meningkatkan penerimaan pajak dalam jangka pendek.

3. Menambah jumlah wajib pajak.

\section{- Subjek Tax amnesty}

Subjek Tax amnesty adalah warga negara Indonesia baik yang ber NPWP maupun tidak yang memiliki harta lain selain yang telah dilaporkan dalam SPT Tahunan Pajak

\section{- Objek Tax amnesty}

Objek Tax amnesty adalah Harta yang dimiliki oleh Subjek Tax amnesty, artinya yang menjadi sasaran dari pembayaran uang tebusan adalah atas Harta baik itu yang berada di dalam negeri maupun diluar negeri.

\section{Landasan Teori}

Kebijakan Tax amnesty adalah terobosan kebijakan yang didorong oleh semakin kecilnya kemungkinan untuk menyembunyikan kekayaan di luar wilayah Negara Kesatuan Republik Indonesia karena semakin transparannya sektor keuangan global dan meningkatnya intensitas pertukaran informasi antar negara. Kebijakan Tax amnesty juga tidak akan diberikan secara berkala. Setidaknya, hingga beberapa puluh tahun ke depan, kebijakan Tax amnesty tidak akan diberikan lagi.

Kebijakan Tax amnesty, dalam penjelasan umum Undang-Undang Pengampunan Pajak, hendak diikuti dengan kebijakan lain seperti penegakan hukum yang lebih tegas dan penyempurnaan Undang-Undang tentang 
Ketentuan Umum dan Tata Cara Perpajakan, Undang-Undang tentang Pajak Penghasilan, Undang-Undang tentang Pajak Pertambahan Nilai Barang dan Jasa dan Pajak Penjualan atas Barang Mewah, serta kebijakan strategis lain di bidang perpajakan dan perbankan sehingga membuat ketidakpatuhan Wajib Pajak akan tergerus di kemudian hari melalui basis data kuat yang dihasilkan oleh pelaksanaan Undang-Undang ini.

\section{Peluang}

dan

Tantangan

Implementasi Tax amnesty di Indonesia

Ada beberapa langkah yang ditempuh pemerintah Indonesia khususnya Direktorat Jenderal Pajak guna meningkatkan penerimaan negara dari sektor pajak, antara lain melaksanakan program Sensus Pajak Nasional. Selain itu melakukan penyempurnaan peraturan untuk menangani tindakan penghindaran pajak, tindakan penggelapan pajak melalui transfer pricing, dan pengenaan pajak final. Selain itu salah satu bentuk upaya atau inovasi lain dalam system perpajakan yang berguna meningkatkan penerimaan pajak tanpa menambah beban baik jenis pajak baru maupun persentase pajak yang sudah ada kepada masyarakat, dunia usaha dan para pekerja adalah melalui program Tax amnesty

Di sisi lain kelemahannya bila diterapkan Tax amnesty adalah tidak serta merta menjamin peningkatan kinerja setoran pajak ke kas negara. Hal ini bisa sebaliknya berpotensi terjadinya,penyelewengan,manipulasi dan tindakan moral hazard lainnya. Para pengusaha yang memperoleh pemutihan pajak akan melakukan penggelapan kewajiban pajaknya.

GAMBARAN

UMUM

PERUSAHAAN/METODE

\section{PENELITIAN}

Lokasi Penelitian dan Gambaran

\section{Umum Perusahaan}

\section{a. Lokasi Penelitian}

Lokasi dalam penelitian ini adalah Bursa Efek Indonesia Kantor Perwakilan Yogyakarta, yang beralamat di Jalan Mangkubumi No. 111, Yogyakarta.

\section{b. Visi dan Misi Perusahaan}

- VISI

Menjadi bursa yang kompetitif dengan redibilitas tingkat dunia.

- MISI

Menciptakan daya saing untuk menarik investor dan emiten, melalui pemberdayaan Anggota Bursa dan Partisipan, penciptaan nilai tambah, efisiensi biaya serta penerapan good governance.

\section{c. Populasi dan Sampel Penelitian}

Data yang digunakan dalam penelitian ini adalah data sekunder 
berupa wawancara langsung terhadap sumber aslinya agar mendapatkan data yang mencerminkan kebenaran berdasarkan dengan apa yang dilihat dan didengar langsung sehingga unsur-unsur kebohongan dari sumber yang fenomenal dapat dihindari.

\section{d. Metode Sampling}

Metoda sampling yang ditempuh di penelitian ini adalah Metode dokumentasi, yaitu pengumpulan data dimana peneliti menyelidiki benda-benda tertulis seperti bukubuku, majalah, dokumen, peraturanperaturan, dan sebagainya. Metode ini digunakan untuk memperoleh data tentang Pengaruh Tax amnesty Bagi Bursa Efek Indonesia di Kantor Perwakilan Yogyakarta.

\section{e. Teknik Pengumpulan Data}

Metode pengumpulan data yang digunakan dalam penelitian ini adalah sebagai berikut:

\section{Wawancara}

Secara garis besar ada dua macam wawancara yaitu wawancara tidak terstruktur dan wawancara terstruktur. Dalam penelitian ini menggunakan wawancara tidak terstruktur karena mewawancarai dalam bentuk komunikasi langsung antara peneliti dan responden tetang garis besar obyek penelitian saja tidak secara lengkap menyeluruh (detail).

\section{Dokumentasi}

Dokumentasi diperoleh dengan melakukan pencatatan atau mencari data-data mengenai hal-hal atau variabel seperti biaya produksi, hasil produksi, dan data lainnya yang berkaitan dengan penelitian di dalam perusahaan.

\section{Metode Analisis Data}

Dalam melakukan penelitian ini metode analisis data yang digunakan adalah:

\section{Analisis Deskriptif Kualitatif}

Analisis ini digunakan untuk membahas dan menerangkan hasil penelitian dengan mempertimbangkan dan membandingkan data yang diperoleh yang akan dikembangkan menjadi hipotesis.

\section{Kesulitan-kesulitan yang timbul selama penelitian}

Data yang diperoleh terbatas karna dilakukan hanya di kantor perwakilan dan data diperoleh melalui web, berita, wawancara serta kunjungan dan waktu yang terbatas jadi penelitian yang diambil serta dibahas tidak banyak.

\section{HASIL DAN PEMBAHASAN}

\section{a. Pengaruh program Tax amnesty}

Jika melihat kondisi saat ini, 
Indonesia sebagai salah satu Negara berkembang yang masih memiliki banyak agenda pembangunan di berbagai sektor, seperti di sektor pendidikan, kesehatan, dan infastruktur, sehingga tentunya membutuhkan biaya pembangunan yang besar. Tidak hanya di Indonesia, sumber pembiayaan untuk pembangunan di berbagai Negara selama ini sebagian besar bertumpu pada penerimaan pajak. Hal ini juga terlihat pada porsi penerimaan perpajakan yang ditargetkan mencapai 84.6\% dari total Anggaran pendapatan dan Belanja Negara (APBN) 2016.

Tax amnesty sesungguhnya dapat menjadi langkah awal dalam memperbaiki lemahnya situasi perpajakan di Indonesia. Terdapat argumentasi bahwa kebijakan Tax amnesty berpotensi mendorong peningkatan kepatuhan pajak secara sukarela (voluntary compliance) di masa mendatang setelah Tax amnesty dilakukan. Hal itu didasari oleh sebuah harapan bahwa setelah dilakukan Tax amnesty, asset atau kekayaan wajib pajak yang sebelumnya berada diluar system administrasi perpajakan akan masuk menjadi bagian system administrasi perpajakan, sehingga kedepannya wajib pajak tidak bias mengelak dari kewajiban perpajakannya. Dengan mencermati permasalahan rendahnya kepatuhan pajak di Indonesia, di mana tingkat kepatuhan akan berpengaruh pada pencapaian penerimaan pajak, maka hal tersebut dapat menjadi salah satu justifikasi atau urgensi segera diterapkannya mekanisme Tax amnesty . Draf Rancangan UndangUndang (RUU) Tax amnesty pun sudah disahkan, Di sisi lain, penerapan kebijakan Tax amnesty seringkali lebih dikaitkan kepada upaya pencapaian target penerimaan pajak jangka pendek. Padahal sejatinya, kebijakan Tax amnesty memiliki tujuan jangka panjang, yaitu untuk meningkatkan kepatuhan dan penerimaan pajak secara berkesinambungan melalui perluasan data dan basis pajak yang diperoleh. Pengumpulan data perpajakan inilah yang akan menjadi modal besar bagi otoritas pajak dalam melakukan penegakan hukum (law enforcement).

b. Seberapa besar pengaruh program Tax amnesty dalam meningkatkan saham pasar modal di Bursa Efek Indonesia?

c. Data kenaikan serta penurunan harga saham di Bursa Efek Indonesia.

\section{PEMBAHASAN}

a) Tabel 4.1 Bursa Efek Indonesia 29 Juni 2016 :

Dilihat dari tabel diatas maka dapat disimpulkan bahwa semua saham 
mengalami kenaikan, ini adalah awal yang sangat baik untuk menyambut Tax amnesty periode pertama. Kenaikan tertinggi Pada saham tanggal 29 Juni 2016 ada pada Miscellaneous Industry Index yaitu sebesar $2.76 \%$ dengan perhitungan sebagai berikut :

Harga Perubahan $=$ Harga Pembukaan Harga Penutupan

$=1.173 .182-1.205 .543$

$=32.361$

Persentase $\quad=\left(\frac{\text { Harga Perubahan }}{\text { Harga Pembukaan }}\right) \mathrm{x}$ $100 \%$

$=\left(\frac{32.361}{1.173 .182}\right) \times 100 \%$

$=2.76 \%$

\section{b) Tabel 4.2 Bursa Efek Indonesia 11} Juli 2016 :

Dilihat di dalam tabel 4.2, bahwa terjadi kenaikan di beberapa saham bursa efek, bila kita amati tabel 4.2 merupakan tabel setelah adanya pengesahan program tax amnesty periode pertama. Dilihat dari tabel diatas maka dapat disimpulkan bahwa hampir semua saham mengalami kenaikan, namun ada saham yang mengalami penurunan yaitu Agriculture Index dan Miscellaneous Industry Index yaitu sebesar $0.72 \%$ dan $1.64 \%$, sedangkan kenaikan tertinggi pada saham tanggal 11 Juli 2016 terjadi pada InfoBank15 yaitu sebesar $3.21 \%$. Dengan perhitungan sebagai berikut :
Harga Perubahan $=$ Harga Pembukaan Harga Penutupan

$=524.930-541.755$

$=16.825$

Persentase $\quad=\left(\frac{\text { Harga Perubahan }}{\text { Harga Pembukaan }}\right) \quad \mathrm{X}$ $100 \%$

$=\left(\frac{16.825}{524.930}\right) \times 100 \%$

$=3.21 \%$

\section{c) Tabel 4.3 Bursa Efek Indonesia 03}

\section{Oktober 2017 :}

Dilihat di dalam tabel 4.3, bahwa terjadi kenaikan di beberapa saham bursa efek, bila kita amati tabel 4.3 merupakan tabel setelah adanya pengesahan program tax amnesty periode kedua yakni tanggal 01 Oktober 2016. Dilihat dari tabel diatas maka dapat disimpulkan bahwa semua saham mengalami kenaikan, ini adalah awal yang sangat baik untuk menyambut Tax amnesty periode kedua sama halnya pada tabel 4.1, Pada saham tanggal 03 Oktober 2016 kenaikan tertinggi terjadi pada Basic Industri and chemicals Index yaitu sebesar $3.13 \%$. Dengan perhitungan sebagai berikut:

Harga Perubahan $=$ Harga Pembukaan Harga Penutupan

$=512.808-528.844$

$=16.036$

Persentase $\quad=\left(\frac{\text { Harga Perubahan }}{\text { Harga Pembukaan }}\right) \mathrm{x}$ $100 \%$

$=\left(\frac{16.036}{512.808}\right) \times 100 \%$ 
$=3.13 \%$

d) Tabel 4.4 Bursa Efek Indonesia 30 Desember 2016 :

Dilihat di dalam tabel 4.4 , terjadi kenaikan serta penurunan di beberapa industry saham, hal ini terjadi pada akhir berlangsungnya program tax amnesty pada periode kedua, kenaikan teritinggi berada pada Miscellaneous Industry Index yakni $1.74 \%$ kenaikan.

Dengan perhitungan sebagai berikut :

Harga Perubahan $=$ Harga Pembukaan Harga Penutupan

$=1.347 .124-1.370 .628$

$=23.504$

Persentase $\quad=\left(\frac{\text { Harga Perubahan }}{\text { Harga Pembukaan }}\right) \mathrm{x}$ $100 \%$

$=\left(\frac{23.504}{1.347 .124}\right) \times 100 \%$

$=1.74 \%$

e) Tabel 4.4 Bursa Efek Indonesia 03 Januari 2017 :

Dilihat di dalam tabel 4.5, Hampir semua saham mengalami penurunan harga saham hanya ada dua saham yang mengalami kenaikan yaitu saham dari Infobank15 dan Mining Index yaitu sebesar $0.14 \%$ dan $0.58 \%$, setelah menyambut tahun baru dan tax amnesty periode ketiga dalam index Bursa Efek Indonesia mengalami penurunan hampir pada semua saham, Penurunan saham terbesar terjadi pada saham dari
Agriculture Index yaitu sebesar $1.15 \%$.

Dengan perhitungan sebagai berikut :

Harga Perubahan $=$ Harga Pembukaan Harga Penutupan

$=1.864 .249-1.842 .848$

$=-21.401$

Persentase $\quad=\left(\frac{\text { Harga Perubahan }}{\text { Harga Pembukaan }}\right) \mathrm{x}$ $100 \%$

$=\left(\frac{-21.401}{1.864 .249}\right) \times 100 \%$

$=-1.15 \%$

f) Tabel 4.5 Bursa Efek Indonesia 16 Maret 2017

Dilihat di dalam tabel 4.5, bahwa terjadi kenaikan di hampir disemua saham bursa efek dan periode terakhir berlangsungnya tax amnesty masih disambut dengan kenaikan saham di beberapa index saham yakni kenaikan terbesar ada pada Miscellaneous Industry Index jika disimpulkan dari beberapa tabel di atas Miscellaneous Industry Index mengalami kenaikan tertinggi pada saat akan di mulainya program tax amnesty dan pada saat akan adanya penutupan program tax amnesty.

Dengan perhitungan sebagai berikut :

Harga Perubahan $=$ Harga Pembukaan Harga Penutupan $=1.385 .322-$ $1.439 .616=54.294$

Persentase $\quad=\left(\frac{\text { Harga Perubahan }}{\text { Harga Pembukaan }}\right) \quad \mathrm{x}$ $100 \%$

$=\left(\frac{54.294}{1.385 .322}\right) \times 100 \%$ 
$=3.92 \%$

g) $\operatorname{Tax}$

amnesty

membuat

pertumbuhan yang signifikan

terhadap Investor pasar modal.

Pengampunan pajak atau tax amnesty yang diberlakukan pemerintah untuk wajib pajak mulai berpengaruh terhadap pasar modal. Banyak masyarakat yang mulai bertanya terkait Tax amnesty dan menjadi investor di pasar bursa yang mereka selenggarakan selama ini. "Investor bertambah cukup signifikan, lebih besar dari rata-rata bulan sebelumnya," ujar Bapak Irfan Noor Riza . Dia mencatat pertumbuhan jumlah investor selama Juli yaitu sejak Tax amnesty diundangkan naik signifikan dibanding akhir Juni. Selama Juli dia mencatat setidaknya ada 1.736 investor baru. Pada bulan tersebut setidaknya ada 17.477 investor lokal yang bermain di pasar bursa. Dia menuturkan, pada Juli terjadi kenaikan investor cukup signifikan dengan total mencapai 18.213 investor. Jumlah investor yang mengalami kenaikan signifikan tersebut diperkirakan akan terus bertambah. Dampaknya turut mendongkrak jumlah transaksi di pasar bursa. BEI Yogyakarta mencatat jumlah transaksi yang dilakukan investor DIY rata-rata Rp373 miliar per bulan.

\section{KESIMPULAN}

Dari pembahasan di atas ada beberapa hal yang dapat di simpulkan antara lain sebagai berikut:

1. Tax amnesty dapat menjadi langkah awal dalam memperbaiki lemahnya situasi perpajakan di Indonesia, Terdapat argumentasi bahwa kebijakan Tax amnesty penting dan sangat berpotensi mendorong peningkatan kepatuhan pajak secara sukarela (voluntary compliance) di masa mendatang setelah Tax amnesty dilakukan.

2. Bursa Efek Indonesia kantor perwakilan Yogyakarta mencatat terjadi pertumbuhan yang signifikan terhadap jumlah investor, pertumbuhan tersebut diperkirakan akan terus bertambah dan turut mendorong kenaikan jumlah transaksi di pasar bursa, Bursa Efek Indonesia kantor perwakilan Yogyakarta mencatat jumlah transaksi yang dilakukan investor DIY rata-rata Rp373 miliar per bulan, jumlah transaksi ini lebih besar dari rata-rata transaksi bulan sebelumnya.

\section{SARAN}

Ada beberapa saran yang dapat disampaikan terkait implementasi Tax amnesty di Indonesia, antara lain sebagai berikut :

1. Penerapan Tax amnesty harusnya 
dibedakan antara wajib pajak

yang berpenghasilan besar,

menengah dan kecil supaya tidak

akan menimbulkan polemik

kedepannya.

2. Untuk proses administrasi pengajuan Tax amnesty jangan terlalu panjang dan menyusahkan buatlah sesimpel mungkin supaya masyarakat dapat mengisi SPT dengan lancar.

\section{DAFTAR PUSTAKA}

Agung, Mulyo, Teori dan Aplikasi Perpajakan Indonesia, Penerbit Dinamika Ilmu, Jakarta, 2007

Santoso, Urip \& Justina, Setiawan. Tax amnesty dan Pelaksanaanya di Beberapa Negara : Perspektif Bagi Pebisnis Indonesia, Kopertis, Volume 11 No. 2 Juli 2009

Silitonga, Erwin, Makalah berjudul : Ekonomi bawah Tanah, Pengampunan Pajak dan Referandum, 2006

Hari S. Luitel, Is Tax Amnesty a Good Policy?, (London: Lexington Books, 2014)

James Alm, "Tax Policy Analysis: the Introduction of a Russian Tax Amnesty ". International Studies Program Working Paper 98-6, Georgia State University Andrew Young School of Policy Studies, (1998): 3

Darussalam, "Mendongkrak pajak dari Underground Economy," Investor Daily, (21 Maret 2011).

Sumber : Forum Diskusi Ilmiah Perpajakan berjudul Tax Amnesty
Perlu Prasarat Tax

Reform(http://groups.yahoo.com/gr oup/forum-pajak/message/10744) 